polluting substances, of the rate at which the water of a stream will absorb oxygen from the air, and of the effects of aquatic plants and animals on the oxygen balance.

In the field, the only satisfactory method at present available for determining the rate of transfer of oxygen from the air is to reduce the oxygen tension in the water (by adding sulphite and a catalyst), following then the rise in level of oxygen below this point. This method has been used successfully for small streams, but presents obvious difficulties in a large river. Many of the factors involved, however-for example, turbulence, and the presence of substances such as detergents in solution which reduce the rate of oxygen transfer-are being investigated by running water through sloping troughs, $100 \mathrm{ft}$. long, in the grounds of the Laboratory. One question which is often important in Britain-namely, the change in oxygen-level in water when it flows over weirs-has been substantially settled by work in the field and in pilot-scale plant ; given the height from which the water falls, and the temperature, the extent to which the oxygen deficit is reduced can be predicted within narrow limits.

In rivers, oxidation and reduction of compounds of nitrogen often play an important part. Oxidation of ammonia and reduction of nitrate, and particularly the effect of concentration of dissolved oxygen on these processes, are being studied in an artificial river in which water passes through a series of tanks fitted with stirrers. In streams containing large numbers of algae or much rooted vegetation, the effects of the bacterial oxidation of polluting matter on oxygen tension may be greatly outweighed by photosynthetic production of oxygen and its consumption by plant respiration. These effects are being studied in a stream near the Laboratory, where continuous recorders are installed. In June and September 1958 there was a net release of $3.8 \mathrm{gm}$. oxygen $/ \mathrm{m} .{ }^{2}$ / day. Estimates are being made of the productivity of different reaches in this stream using cropping techniques assisted by aerial photographs taken by a camera suspended from a meteorological balloon. Consumption of oxygen by respiration of invertebrates is also significant, and this is being determined in respirometers in which the change in oxygen tension is again recorded continuously.

The Laboratory has a small but well-equipped Microbiological Section in which three main lines of work are in progress. The first is a detailed study of the changes which occur when aqueous solutions of organic compounds (which may be radioactively labelled) are passed over an active microbial film of the type which occurs in percolating filters and on which the purification of sewage by this process depends. The film is built up on the inside of a 'Perspex' cylinder, the long axis of which is inclined and about which it is rotated; the atmosphere in contact with the film is circulated and there are arrangements for withdrawing samples from it and for adding oxygen to replace that used in oxidation. Most of the organic substances present in such materials as sewage are very rapidly oxidized; one object of the work is to identify those which are not.

It is very important, in treating polluting liquids by biological processes, to be able, in the last stage of the process, to remove by sedimentation organic sludge from the liquid-the latter representing, of course, the final effluent from the plant. A large part of the organic matter to be removed consists of bacteria and the quality of the final effluent depends very largely on whether they will or will not agglutinate in the final sedimentation tank. In spite of a good deal of work on the subject, not much is known of the factors which affect flocculation in a treatment plant; these are therefore being studied by the section, using cultures isolated from sewage and sewage effluents.

The third line of work which is being pursued in collaboration with the National Coal Board is on the bacterial treatment of waste waters from coke ovens, in which the chief constituents to be removed are phenols, thiocyanate and ammonia. Rates of assimilation and oxidation of these substances are being studied in continuous-culture apparatus after preliminary trials by the usual Warburg technique.

The Microbiological Section has recently been strengthened by the transfer to it of some of the staff formerly working at the National Chemical Laboratory.

\title{
WATER SUPPLY AND DEMAND IN GREAT BRITAIN
}

$\mathrm{T}$ THE problem of water supply and demand, the need for improved hydrological knowledge and the necessity for a continuing study of the changing situation in Britain, have received editorial notice in earlier issues of Nature $(172,823 ; 1953$, and 176 , 1133 ; 1955). The decision to suspend the Inland Water Survey and disband the Central Advisory Water Committee during the economy measures of 1952 was, from a purely scientific point of view, strongly criticized. Happily this decision was reversed in 1955 when the Central Advisory Water Committee was reconstituted; and in the same year the Inland Water Survey also recommenced its labours and has since published a great deal of information covering the post-war years.

One of the first actions taken by the Central Advisory Water Committee in 1955 was to appoint two subcommittees to investigate information on water resources and the growing demand for water. Both these subcommittees have recently reported to the Central Committee and the information collected so far has now been published*.

Of the two documents, that of the Subcommittee on Information on Water Resources is perhaps the least controversial and may be considered first. This Subcommittee was appointed with the following terms of reference : (i) to review the current activities which contribute to our knowledge of the nation's water resources; (ii) to define the additional work needed to make a balanced survey of the quantity and quality of surface and underground water available for domestic, industrial and agricultural use; (iii) to advise on ways of collecting and interpreting * Central Advisory Water Committee. Subcommittee on The Growing Demand for Water-First Report. Pp. iv +28 . 18. 3d. net.
Report of the Subcommittee on Information on Water Resources. Report of the Subcommittee on Information on Water Resources.
Pp. ii +20 . 1s. $3 d$. net. (London: H.M. Stationery Office, 1959.) 


\section{No. 4688 September 5, $1959 \quad$ N A T UR E}

the necessary information, correlating it with informa. tion from other sources and publishing it.

The review of current activities deals with the work of the Meteorological Office (Air Ministry), the Surface Water Survey Centre (Ministry of Housing and Local Government) and the Geological Survey in providing information on rainfall, evaporation, surface water and ground water. It is recommended that the Geological Survey should resume publication of information on ground water; and that all data on rainfall, surface water and ground water should be presented on a common basis of river basin areas. The planned future contents of "British Rainfall" and the "Surface Water Year Book" are endorsed, and the proposed arrangements for the collection and interpretation of hydrological information are considered adequate to meet the known need, although certain extensions of existing activities are recom. mended. The more frequent inspection of rainfall stations, the more accurate recording of snowfall, additional recording of ground water, the publication of more data on the quality of certain water supplies and the more rapid completion of the network of river gauging stations are all considered desirable.

Although the arrangements for the collection and interpretation of information are considered "broadly [to] meet the known need", the report recognizes the neressity for additional investigation into hydrological relationships and for further inquiry into the use of hydrological information. It is there. fore also recommended that work at present being done on hydrological research should be reviewed to determine how such work should be co-ordinated and what extensions or modifications may be desirable. The lack of any central hydrological information and research organization comparable to the Geological Survey or Meteorological Office has already been noted elsewhere*. The publication of this report on information on water resources realiy arises from the lack of such a body, since data on the hydrological cycle in Great Britain are scattered among such a variety of authorities: each of these authorities is only interested in one aspect of the complete cycle. The recommendation that all hydrological results should be presented on a common basis of hydrometric areas is, however, a significant move towards a closer integration of the available data.

The report of the Subcommittee on the Growing Demand for Water is a longer document, although despite three years deliberation and investigation it has appeared as a first and not as a final report, for the subcommittee found its terms of reference more exacting than anticipated. These were "To consider the extent to which the demand for water for domestic, industrial, agricultural and other purposes is increas. ing and is likely to increase, to consider the problems involved in moeting these demands, including, in broad terms, the cost; to consider whother there are any substantial economies in the use or cost of water which could be made without reduction in standards of hygiene or in industrial or agricultural efficiency; and to make recommendations".

The main questions which remain unanswered concern the demand for water for agricultural irrigation and economies in the use of water in industry. The chief difficulty experienced in the investigation was related to the dual character of water supply in Great Britain which is provided by both public water undertakers and obtained privately: and the threefold noture of the demand, which is domestic,

* Balchin, W. G. V., Water and Water Ena., 61, No. 734 (1957). industrial and agricultural. Accurate statistical information on consumption is readily available only from the public water undertakers, but even here the amounts in the various categories of use are not fully known. The subcommittee instituted its own official inquiry among all public water undertakers, the nationalized industries (electricity, coal, gas and transport), and six major industries (brewing, chemieals, iron and steel, leather, paper and textiles) where supplies are largely obtained privately. A large and valuable collection of new statistical data has therefore been accumulated; and this, together with the unpublished water surveys carried out between 1945 and 1958 by engineers of the Ministry of Housing and Local Government, form the basis of the recommendations accompanying the report.

In the industrial and domestic categories there is clear evidence of a steady nation-wide increase in water consumption of between 2 and 3 per cent per annum during the past quarter of a century. This is expected to continue into the future to produce by 1965 something of the order of a 25 per cent increase over the known 1955 consumption figures. As new works under construction, or proposed, are scheduled to yield an additional 800 million gallons of water a day by 1965 , and this is approximately 40 per cent of the quantity distributed by water undertakers in 1955, the subcommittee concludes that in England and Wales as a whole the rising consumption need not give rise to immediate anxiety. This general statement is, however, immediately qualified with the proviso that "this is not to say that temporary or loeal shortages will not recur from time to time, quite, apart from more general shortages in very dry years (when maximum domestic demand and minimum supply tend to coincide), or that industries seeking new sites will find abundant supplies in any place they care to choose". The estimates also assume that in any particular area the trend of consumption will follow approximately its present course, so that any significant deviation not foreseen at present could upset the balance.

Beyond 1965 the Subcommittee was "unable to obtain any reliable data" and decided not to attempt numerical estimates. The subcommittee is therefore not prepared to commit itself other than to express the opinion that there need be no shortage of water in any part of England and Wales provided that development schemes are prepared well in advance of demand, that the necessary statutory powers and other authorizations are granted, that capital investment is permitted on the requisite scale and the location of industries which require large quantities of water is regulated with the water supply situation in mind.

While acknowledging the great amount of work which has clearly gone into the inquiry, and the valuable new information which the report presents, it must be admitited that there are a number of debatable points. In the first instance the Subcommittee has based its arguments upon figures of past consumption which are not necessarily indicative of past demand, and could certainly be misleading so far as future demand is concerned. This is most evident in the agricultural usage of water. Quite apart from the fact that the consumption rises rapidly as soon as piped water bocomes available to a farm, there is the whole unresolved and rapidly growing problem of agricultural irrigation. The work done at Rothamsted Experimental Station shows, for agriculture, a deficiency of rain in more than five years out. 
of ten south of a line drawn from the Humber to the Severn, and a deficiency in nine years out of ten in Essex, Suffolk and Kent. The magnitude of the deficiency varies from place to place and from year to year with theoretical values ranging from $l$ in. to 12 in. of rain. The irrigation that would be needed to meet this deficiency would depend on soil moisture retention conditions and plant rooting characteristics, and might amount to a rainfall equivalent in some places of up to 6 in. All the water would be used in transpiration or evaporation, or absorbed by percolation, and would not be capable of re-use. Calculations indicate that a possible demand of some 8,000 million gallons a day might exist in very dry years south of the Humber-Severn line. This amount is more than four times that supplied in $\mathbf{1 9 5 5}$ by all the public water undertakers in England and Wales, and it indicates the potential demand which exists and which the subcommittee has ignored in its first report. It is proposed, however, to give further attention to this problem, but the approach appears to be negative as the possibility is mentioned of some form of control over the abstraction of surface water analogous to the existing protection of underground water. If the national policy is to secure the maximum food output from the agricultural industry, farmers in south-east England should be actively encouraged rather than discouraged to irrigate, in which case a more positive approach to the water supply problem and a completely different attitude of mind are then needed.

The reluctance of the Subcommittee to look further ahead than 1965 is also unfortunate, although the difficulties can be fully appreciated. The Ministry of Health Committee on Causes of Increase in Consumption of Water (1949) was prepared to look ahead for a period of some 22 years up to 1970 . Past experience clearly shows that water-supply schemes take many years to come into operation and that reliability in supply largely depends on one generation planning for the next. The blue prints to meet the requirements of the late 1970's should be in process of formulation in the early 1960's if the real needs of agriculture and industry are to be satisfied.

Possible economies in the use of water in industry have also been deferred for future consideration, although the report does direct attention to waste prevention and leak detection; the recommendation is made that all water undertakers should operate an adequate waste prevention service.

There is clearly much food for thought in both of these reports. The rising standard of living of an increasing population in Great Britain has, in the present century, brought water to the forefront as a vital and essential commodity in the life of the nation. Although the natural resources of the country in terms of rainfall are theoretically adequate, Nature has a habit of distributing the precipitation unevenly in both time and place. This situation can only be remedied by care in use and by the conservation of supplies in periods and areas of plenty. Lowland Britain, where consumption is greatest, is also the area where the population is densest, the rainfall least and where local water resources are nearing full utilization. Highland Britain, on the other hand, has a low population, the highest rainfall and a relative over-abundance of water of which only a small proportion has yet been developed. To what extent would the gains from scientific irrigation in agriculture and a guaranteed domestic and industrial supply in lowland Britain outweigh the cost of storage and movement of water from highland Britain? And how far might the conversion of saline water in Great Britain assist in the solution of the watersupply problem? It seems that these are tho major questions on water supply that must be answered if the problem is to be approached with vision and concern for the needs of the next generation.

W. G. V. Batchin

\section{TEN YEARS OF ERGONOMICS}

$\mathrm{E}^{\mathrm{B}}$ RGONOMICS is mainly about 'human factors' in the design and operation of machines, and about the physical environments in which men use their machines. Moreover, it is multidisciplinary. Nobody who attended the tenth anniversary meeting of the Ergonomics Research Society, held in Oxford during April 6-9, could have much doubt on either of these points.

The Postmaster-General, Mr. Ernest Marples, apparently less damaged than he should have boen by a 400-mile cycling trip in France on what seems to have been a highly unergonomic saddle, opened the conference. He had hard things to say about the word 'ergonomies'. Unlike his chairman, the Master of Balliol, who thought it was splendid because it told us exactly what it meant, Mr. Marples thought it was frightful because it did not. However, for ergonomics itself he had nothing but praise. The General Post Office had used it for nine years; and it was his intention to build it into the General Post Office structure so firmly that it could be got out again only by 'positive action'. He pledged his support for everyone, everywhere, including housewives in their kitchens, who moved ergonomically with the times.
Following up a point Mr. Marples made about the frequeney with which "backroom boys" are either not understood or misunderstood, Sir Frederic Bartlett, formerly-for twenty-one years-professor of experimental psychology in the University of Cambridge, inquired how common difficulties of communication might be overcome, so that proved advances (for example, in the design of altimeters) might be adopted with reasonable rapidity. Mr. Marples advised him to get into touch with the top people concerned, or with the Parliamentary and Scientific Committee, or with Mr. Marples himself. Sir Frederic looked rather less happy about this than did Mr. Marples.

There was more to come from the General Post Office. A paper by Dr. R. Conrad, of the Medical Research Council Applied Psychology Unit at Cambridge, dealt with mass communication systems; and a couple by Dr. W. F. Floyd, of the Middlesex Hospital Medical School, and Miss June I. Jones, of the General Post Office, covered some problems of lighting, posture, thermal conditions and energy cost of work in telephone exchanges and Post Office factories. These gave a clear indication of what ergonomics amounted to in practice. Dr. Conrad told us that to obtain a weather report he had to 